\title{
Rapid expression and purification of the hepatitis delta virus antigen using the methylotropic yeast Pichia pastoris
}

Stephanie P. Cartwright ${ }^{1}$, Roslyn M. Bill1, Bui Tien Sy², Hieu Tran-Van ${ }^{3}$ and Hung Minh Nguyen ${ }^{*}$

\begin{abstract}
Objective: Patients with dual hepatitis B (HBV) and hepatitis D (HDV) virus infection are at an increased risk of progression to liver cirrhosis and hepatocellular carcinoma than patients with a single viral infection. Treatment of viral hepatitis due to dual HBV/HDV infection represents a challenge. Currently there is no vaccine against HDV. Recombinant production of HDV antigen (HDAg) is the first step towards a potential vaccine candidate and the development of assays for HDV detection.

Results: This study demonstrates the expression of one HDAg isoform, S-HDAg, in Pichia pastoris. A recombinant vector carrying a tagged gene encoding S-HDAg under the control of the methanol-inducible promoter AOX1 was designed and integrated into P. pastoris X33. The protein, which was purified using a $\mathrm{Ni}^{2+}$ affinity column and eluted at 100-150 mM imidazole, has potential as a recombinant antigen for further study.
\end{abstract}

Keywords: Hepatitis delta virus, HDAg, Pichia pastoris, Protein expression

\section{Introduction}

It is estimated that $\sim 240$ million people are chronic hepatitis B surface antigen (HBsAg) carriers, of which 15-20 million are also infected with hepatitis delta virus (HDV) [1-3]. The HDV virion comprises an RNA genome, a single HDV-encoded antigen (HDAg) and a lipoprotein envelope provided by HBsAg [4-7]. HDAg comprises two isoforms, small HDAg (S-HDAg) and large HDAg (L-HDAg) [8, 9]. These two isoforms share the same core sequence, but L-HDAg is extended by an additional 19 amino acids at the carboxyl terminus of S-HDAg. S-HDAg may represent a candidate for human vaccine development. Protection induced by immunization of adjuvanted S-HDAg (p24) was evaluated in woodchucks challenged with HDV by measuring humoral- and $\mathrm{T}$ cell-mediated responses to HDAg [10]. In another study, a DNA vaccine expressing S-HDAg generated a higher titer of anti-HDV antibodies than one expressing

\footnotetext{
*Correspondence: hungmolbio@gmail.com

${ }^{4}$ Center for Molecular Biology, Institute of Research and Development,

Duy Tan University, K7/25 Quang Trung, Da Nang City, Viet Nam

Full list of author information is available at the end of the article
}

L-HDAg [11]. However, efforts to characterize and evaluate the immunological properties of S-HDAg have been limited due to the lack of proper methods for efficient expression and purification of S-HDAg. In this work, we present a short procedure to express and detect S-HDAg in Pichia pastoris culture medium.

\section{Main text \\ Methods \\ PCR amplification of the S-HDAg gene}

Two primers, HDAg-F: 5'-GCTCTAGATTTGG GAATCCCTGGTTTCC- $3^{\prime}$ and HDAg-R: 5'-GCGG TACCATGAGCCGGTCCGAATCG-3' ${ }^{\prime}$ (XbaI and KpnI sites underlined, respectively), were used to amplify the $S-H D A g$ gene. The volume of the PCR reaction was $50 \mu \mathrm{L}$ including: $1 \times$ Phusion buffer, $0.2 \mathrm{mM}$ dNTP (NEB, N0446S), $0.5 \mathrm{mM}$ each primer (IDT) and $5 \mathrm{ng}$ pHDV3 plasmid as a template, $1 \mathrm{U}$ Phusion High-Fidelity DNA polymerase (NEB, M0530S). The PCR reaction was performed by using the following program: $98{ }^{\circ} \mathrm{C}$ for $30 \mathrm{~s} ; 30$ cycles of $\left(98{ }^{\circ} \mathrm{C}\right.$ for $10 \mathrm{~s}, 55^{\circ} \mathrm{C}$ for $30 \mathrm{~s}, 72{ }^{\circ} \mathrm{C}$ for $\left.30 \mathrm{~s}\right)$ and final extension at $72{ }^{\circ} \mathrm{C}$ for $5 \mathrm{~min}$. The PCR product was analyzed by electrophoresis using a $1 \%(\mathrm{w} / \mathrm{v})$ agarose 
gel (BioBasic, D0012) and visualized by Red-Safe Solution (iNtRON, 21141) on a Blue LED Illuminator. The desired DNA band $~ 590$ bp was excised from the gel and purified by QIAquick Gel Extraction Kit (Qiagen, 28706) following manufacturer's instructions.

\section{Cloning of the S-HDAg gene into pPICZaA}

Enzymatic digestion and ligation The purified S-HDAg gene and vector pPICZ $\alpha$ A (TFS, V19520) were digested with XbaI and KpnI (NEB, R0145S and R0142S, respectively) and purified by QIAquick PCR Purification Kit (Qiagen, 28106) following the manufacturer's instructions. The digested HDAg gene was ligated into the linearized vector pPICZ $\alpha$ A using T4 DNA ligase (NEB, $\mathrm{M} 0202 \mathrm{~S})$. The reaction was performed in a $20 \mu \mathrm{L}$ volume including $2 \mu \mathrm{L} 10 \times$ Rapid Ligation Buffer, $8 \mu \mathrm{L}$ DNA ( $100 \mathrm{ng}), 1 \mu \mathrm{L} 5 \mathrm{U} / \mu \mathrm{L}$ T4 DNA ligase and incubated at $22{ }^{\circ} \mathrm{C}$ for $2 \mathrm{~h}$.

Transformation and screening of E. coli $10 \mu \mathrm{L}$ of the ligation mixture was transformed into competent $E$. coli DH $5 \alpha$ cells by heat shock at $42^{\circ} \mathrm{C}$ for $30 \mathrm{~s}$. The cells were then recovered by adding $500 \mu \mathrm{L}$ liquid LB medium and incubating at $37^{\circ} \mathrm{C}$ for $1 \mathrm{~h}$ and then plated on LB plates supplemented with $25 \mu \mathrm{g} / \mathrm{mL}$ Zeocin (TFS, R25001). After incubated at $37^{\circ} \mathrm{C}$ overnight, ten colonies were cultured in $3 \mathrm{~mL}$ liquid LB medium supplemented with $25 \mu \mathrm{g} / \mathrm{mL}$ Zeocin at $37{ }^{\circ} \mathrm{C}$ overnight. The recombinant plasmids were isolated from the cell pellets using a GeneJET Plasmid Miniprep kit (TFS, K0503) following the manufacturer's instructions and digested using $\mathrm{Xba \textrm {I }}$ and $\mathrm{Kp} n \mathrm{I}$ for screening positive plasmids carrying the $S-H D A g$ gene.

\section{Sequencing and analysis}

In order to confirm positive clones, purified plasmid was used for nucleotide sequencing. $5 \mu \mathrm{L}$ of eluted plasmid was subjected to cycle sequencing with $1.0 \mu \mathrm{L}$ of the ABI Prism BigDye terminator cycle sequencing ready reaction kit (ABI) using $0.5 \mu \mathrm{L}$ of $5^{\prime} \mathrm{AOX}-\mathrm{F}$ : 5'-GACTG GTTCCAATTGACAAGC-3' on the AOX1 promoter and 3'AOX1-R: 5'-GCAAATGGCATTCTGACATCC-3' on the $A O X 1$ terminator. Consensus sequences were generated by alignment of both sequenced strands after validation using DNAstar software V7.

\section{Expression of recombinant S-HDAg in P. pastoris}

Plasmid preparation A positive colony of $E$. coli was cultured at $37^{\circ} \mathrm{C}$ overnight in $50 \mathrm{~mL}$ liquid LB medium supplemented with $25 \mu \mathrm{g} / \mathrm{mL}$ Zeocin. The recombinant plasmid (pPICA $\alpha$ A-S-HDAg) was then isolated by GenElute Plasmid Midiprep kit (Sigma-Aldrich, NA0200) following the manufacturer's instructions and linearized using PmeI (NEB, R0560S). The linearized plasmid was then separated on a $1.5 \%$ agarose gel and purified by Wizard SVGel and PCR Clean-Up System (Promega, A9281) following the manufacturer's instructions.

\section{Transformation and screening of yeast}

Transformation $5 \mu \mathrm{g}$ of the linearized recombinant vector was transformed into $50 \mu \mathrm{L}$ of competent P. pastoris X33 or SMD1163 cells using a Gene-pulser electroporator (Bio-Rad) at $1800 \mathrm{~V}(25 \mu \mathrm{F}, 600 \Omega)$ in a $10 \mathrm{~mm}$ gap electroporator cuvette. After adding $1 \mathrm{~mL} 1 \mathrm{M}$ ice-cold sorbitol, the cells were recovered at $30^{\circ} \mathrm{C}$ for $2 \mathrm{~h} .100 \mu \mathrm{L}$ of the transformation mixture were then plated on YDPS plates supplemented with 100,500 and $1000 \mu \mathrm{g} / \mathrm{mL}$ Zeocin and then incubated at $30{ }^{\circ} \mathrm{C}$ for $2-3$ days until colonies appeared.

Induction on a small scale For expression screening, 24 colonies of each parent strain, X33 or SMD1163, were cultured at $30{ }^{\circ} \mathrm{C}$ in $2.5 \mathrm{~mL}$ liquid BMGY media without Zeocin in a Micro-24 plate (Corning) to $\mathrm{A}_{600}$ around 15-20. Cells were centrifuged and transferred to $10 \mathrm{~mL}$ induction BMMY medium. Cells and culture media were harvested every 24 -h post-induction. $1 \%$ methanol was added every 24 -h post-induction.

Secreted protein preparation Cultures were centrifuged at $5000 \mathrm{rpm}$ for $3 \mathrm{~min}$ and $20 \mu \mathrm{L}$ of the supernatant was taken forward for immunoblot analysis.

Intracellular protein preparation Cell pellets were used to determine total, intracellular protein. $1 \mathrm{~mL}$ breaking buffer $\left(50 \mathrm{mM} \mathrm{Na} \mathrm{HPO}_{4}, 50 \mathrm{mM} \mathrm{NaH} \mathrm{PO}_{4}, 2.0 \mathrm{mM}\right.$ EDTA, pH 7.4, $100 \mathrm{mM} \mathrm{NaCl}$ and 5\% glycerol; pH 7.4), $2.0 \mu \mathrm{L}$ protease inhibitor (Calbiochem) and $200 \mathrm{mg}$ glass bead were added to the cell pellets. The cells were then lysed by breaking at $50 \mathrm{~Hz}$ for $3 \mathrm{~min}$ in a Tissue Lyser LT (Qiagen). The supernatant was transferred to a $1.5 \mathrm{~mL}$ Eppendorf and centrifuged at 13,000 rpm for $15 \mathrm{~min}$. The cell lysate was used for immunoblot analysis.

Immunoblot For detection of the HDAg-His-tag fusion protein, immunoblotting was used to detect the $\mathrm{His}_{6}$-tag fused to the HDAg protein in the supernatant (culture medium) or intracellular protein (cell lysate). $20 \mu \mathrm{L}(10 \mu \mathrm{g}$ ) of each sample and $5 \mu \mathrm{L}$ Protomarker pre-stained protein ladder (National Diagnostics) (10-225 kDa) were applied onto a $12.5 \%$ SDS gel and run in $1 \times$ Tris/glycine/SDS (GeneFlow) at $100 \mathrm{~V}$ for $1 \mathrm{~h}$. The SDS gel was transferred on to a nitrocellulose membrane (Whatman, 09-301-111), blocked in $5 \%$ milk in $1 \times$ PBS buffer and incubated with primary antibody $(6 \times$ His monoclonal antibody (Serotec) 
at a 1:5000 dilution at room temperature for $1 \mathrm{~h}$ ). After washing with $1 \times$ PBST, the membrane was incubated with secondary antibody against mouse IgG conjugated with HRP (Sigma, A0545) at a 1:5000 dilution for $1 \mathrm{~h}$. After washing with $1 \times$ PBST, protein bands on the membrane were detected using EZ-ECL chemiluminescence solution (Geneflow, 20-500-120) and visualized using a Uvitec instrument.

\section{Nickel affinity purification}

Recombinant protein was purified a using a His-trap column. Total secreted protein from $300 \mathrm{~mL}$ culture broth was dialyzed against binding buffer $(300 \mathrm{mM} \mathrm{NaCl}, 10 \mathrm{mM}$ imidazole, $50 \mathrm{mM} \mathrm{NaH}{ }_{2} \mathrm{PO}_{4}$, pH 8.0; Sigma-Aldrich, 56750) which was also used as the binding and equilibration solution. A $5 \mathrm{~mL}$ His-trap HP column (GE Healthcare) was equilibrated with 5 column volumes of binding buffer. All dialyzed protein $(5 \mathrm{mg})$ was loaded into the column with a flow rate of $1 \mathrm{~mL} / \mathrm{min}$ for $50 \mathrm{~min}$. The column was washed with 5 column volumes of binding buffer followed by 5 column volumes of wash buffer $(300 \mathrm{mM} \mathrm{NaCl}, 30 \mathrm{mM}$ imidazole, $50 \mathrm{mM} \mathrm{NaH}_{2} \mathrm{PO}_{4}$, $\mathrm{pH}$ 8.0). The protein was eluted with elution buffer $(300 \mathrm{mM} \mathrm{NaCl}, 250 \mathrm{mM}$ imidazole, $50 \mathrm{mM} \mathrm{NaH}_{2} \mathrm{PO}_{4}, \mathrm{pH} 8.0$ ) at a flow rate of $1 \mathrm{~mL} / \mathrm{min}$ for $20 \mathrm{~min}$. Each $1 \mathrm{~mL}$ fraction was analyzed by SDS-PAGE and visualized using a silver staining kit (Sigma-Aldrich). The protein concentration of the eluted fractions was quantified using a Bradford kit (BioBasic).

\section{Results}

\section{Cloning and sequencing}

A 589 bp fragment comprising the $H D A g$ gene was amplified by PCR (Fig. 1a). The PCR amplicon was cloned into the vector pPICZ $\alpha \mathrm{A}$ by enzymatic digestion and ligation. To confirm this, the recombinant vector pPICZ $\alpha A-S-H D A g$ was digested with $\mathrm{Xba \textrm {I }}$ and $K p n \mathrm{I}$. Two bands of 589 and 3567 bp in length were produced as expected (Fig. 1b, c). To ensure the $S$ - $H D A g$ gene was in frame, two primers $5^{\prime} \mathrm{AOX} 1-\mathrm{F}$ and $3^{\prime} \mathrm{AOX} 1-\mathrm{R}$ were used for sequencing a segment of the recombinant vector pPICZ $\alpha$ A-S-HDAg (Fig. 1d). As shown in Fig. 1e, the $H D A g$ gene was cloned into vector pPICZ $\alpha$ A and located between the $\alpha$-factor at the $5^{\prime}$-end and the hexa histidinetag at the $3^{\prime}$-end. The linearized recombinant vector pPICZ $\alpha \mathrm{A} / \mathrm{S}-\mathrm{HDAg}$ was transformed into freshly-prepared competent $P$. pastoris X33 or SMD1163 cells. Positive colonies were screened based on their resistance to Zeocin due to expression of the Zeocin resistance gene.

\section{Protein expression and purification}

To test the expression levels of the HDAg-His-tag fusion protein, 24 positive colonies of each yeast strain were cultured in $2.5 \mathrm{~mL}$ BMGY media in a Micro-24 microplate and transferred into $10 \mathrm{~mL}$ BMMY supplemented with $1 \% \mathrm{v} / \mathrm{v}$ methanol as an inducer at three time points: 24,48 and $72 \mathrm{~h}$ of induction. Under the control of the promoter $A O X 1$ (methanol inducible promoter), the $S$ - $H D A g$ gene was expressed in P. pastoris X33 but not in SMD1163. For the X33 strain, the expressed protein signal was detected in the culture medium after 48 and $72 \mathrm{~h}$ of induction, while no signal was detected in the cell lysate at all three induction time points. A clear band at $25 \mathrm{kDa}$ was observed by immunoblot (Fig. 2). This is the expected size of the recombinant protein including $\alpha$-factor, S-HDAg, c-myc epitope, and $\mathrm{His}_{6}$-tag. The recombinant protein was purified exploiting its fused $\mathrm{His}_{6}$-tag. The protein eluted at imidazole concentrations from 108-144 mM (wells 4-7, Fig. 3), but not at other concentrations (data not shown). This protein had a molecular weight of $25 \mathrm{kDa}$ which is similar to the predicted molecular weight of the recombinant protein. The yield of purified protein was $115 \mu \mathrm{g} / \mathrm{L}$ culture medium.

\section{Discussion}

S-HDAg may present a good candidate for HDV vaccine development and for diagnostic assays of HDV, but its characterization and immunological evaluation are still limited. One reason is that expression and purification are not effective [12]. For example, expression of the S-HDAg protein has been performed in several cells including E. coli $[13,14]$ and baculovirus/insect cells. However, the former lacks the systems for post-translational modifications and the latter results in rapid degradation of the HDAg protein after 2 days post-infection $[12,15]$. The insertion of the $H D A g$ gene into the chromosome of animal cells resulting in a stable cell-line is a good choice, but this is yet to be reported because HDAg is a nuclear protein and the accumulation of this protein results in significant cytotoxicity. In 1990, a number of HDAg-positive HeLa clones were developed, but these cells were lost in culture, whereas a proportion of HDAgpositive HepG2 clones were expanded successfully [16], suggesting that HDAg cytotoxicity may contribute to the cytopathic nature of HDV that was postulated previously [17]. Transient expression in mammalian cells mediated by viral systems (e.g. vaccinia virus) may be possible as well, however these viruses result in cell death and lysis.

Post-translational modifications have been demonstrated to participate in modulating properties and functions of several proteins $[18,19]$. HDAg has been identified as being post-translationally modified, which is important for its RNA replication and cellular localization [20]. Yeast expression systems in general, and in particular $P$. pastoris, have several advantages such as being 


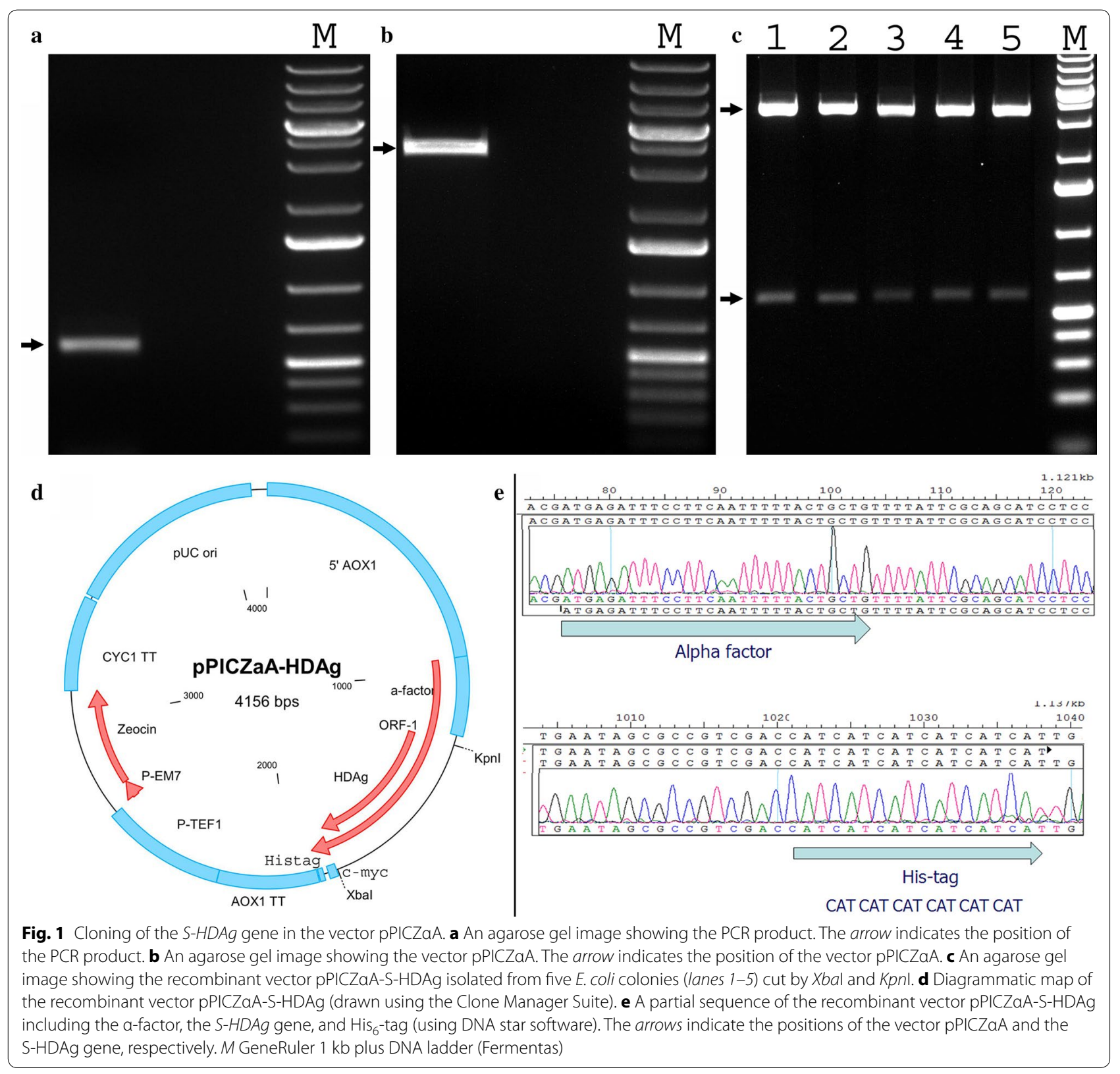

able to perform eukaryotic post-translational modifications. In this study, the HDAg antigen was expressed for the first time in P. pastoris and secreted into the culture medium, which aids in purification of the protein. This preliminary finding will aid further studies of the S-HDAg protein.

\section{Limitations}

Our study had some limitations. We examined the expression of only one HDAg isoform, S-HDAg, in P. pastoris. We also did not address scale-up of the recombinant protein. Finally, we did not characterize the immunological properties of the purified recombinant HDAg protein. 


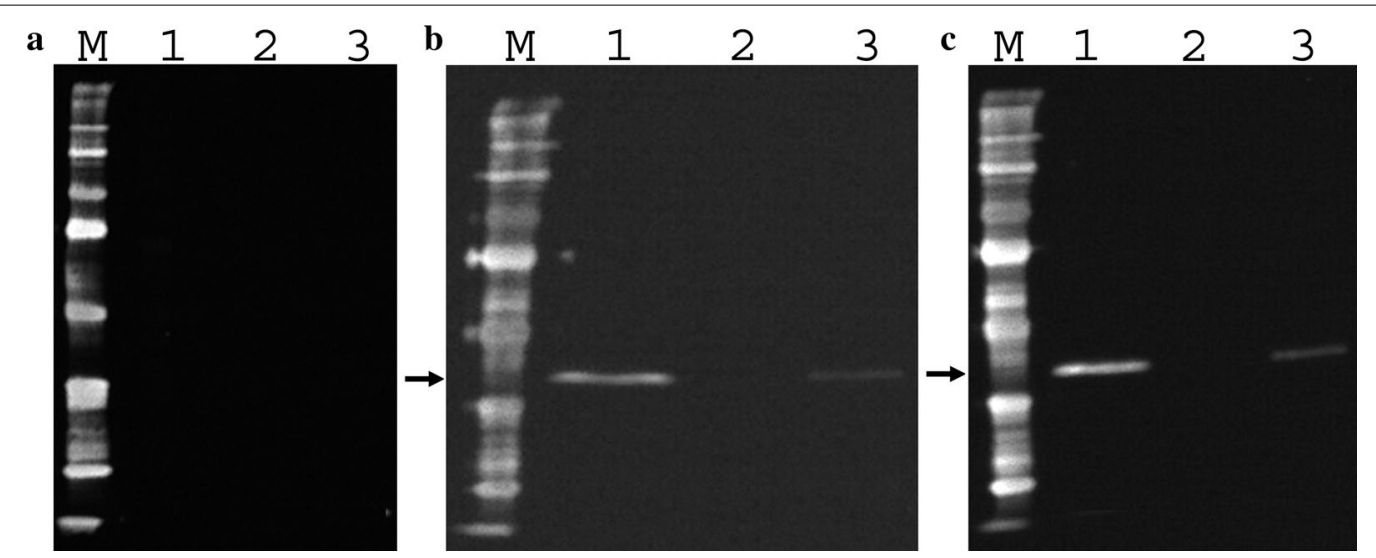

Fig. 2 Expression of the S-HDAg-His 6 -tag fusion protein. An SDS-PAGE gel image showing the expression of the S-HDAg-His 6 -tag fusion protein after a 24-h, b 48-h and $\mathbf{c}$ 72-h induction. Lanes 1-3 indicate three colonies, of which lanes 1 and 3 show recombinant protein expressed after 48-h and 72-h induction; $M$ are Protomarker Protein Markers (National Diagnostics). Protein was probed with a $6 \times$ His monoclonal antibody (Serotec)

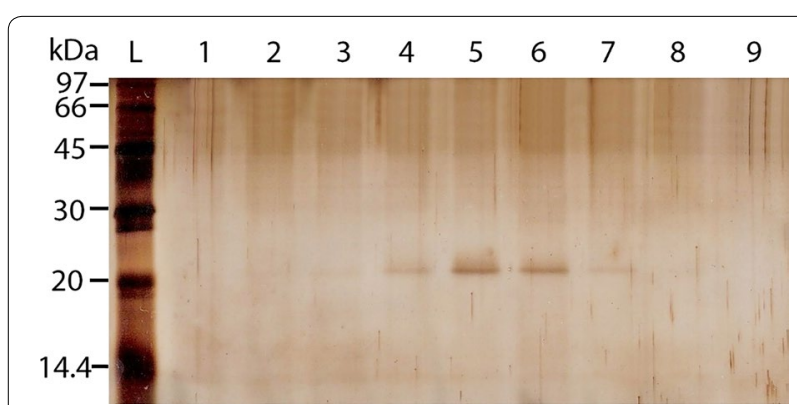

Fig. 3 Purification of S-HDAg-His 6 -tag fusion protein using nickel affinity chromatography. $L$ indicates protein ladder; $1-9$ are eluted fractions which have imidazole concentrations ranging from 72 to $156 \mathrm{mM}$ (the concentration interval between 2 consecutive fractions is about $12 \mathrm{mM}$ ). The gel was visualized by silver staining
Availability of data and materials

All data and materials present in the main paper.

\section{Consent for publication}

Not applicable.

\section{Ethics approval and consent to participate}

Not applicable.

\section{Funding}

This work was sponsored by Vietnam's National Foundation for Science and Technology Development (NAFOSTED) Grant No. 106-YS.02-2014.03 and British Council for granting a fellowship to H.M.N.

\section{Publisher's Note}

Springer Nature remains neutral with regard to jurisdictional claims in published maps and institutional affiliations.

Received: 1 September 2016 Accepted: 26 July 2017

Published online: 27 July 2017

\section{Abbreviations}

BMMY: buffered methanol-complex medium; BMGY: buffered glycerol-complex medium; E. coli: Escherichia coli; HDAg: hepatitis delta antigen; LB: Luria Broth; MCS: multiple cloning sites; YPD: yeast extract peptone dextrose.

\section{Authors' contributions}

$H M N$ and RMB designed the research; HMN, SPC, and HTV performed the research; HMN, BTS and HTV analyzed data; and HMN, SPC, BTS, HTV and RMB wrote the paper. All authors read and approved the final manuscript.

\section{Author details}

${ }^{1}$ School of Life \& Health Sciences, Aston University, Aston Triangle, Birmingham B4 7ET, UK. ${ }^{2}$ Department of Molecular Biology, 108 Military Central Hospital, 1 Tran Thanh Tong, Ha Noi City, Viet Nam. ${ }^{3}$ Faculty of Biology and Biotechnology, University of Science, Vietnam National University, Ho Chi Minh City, Viet Nam. ${ }^{4}$ Center for Molecular Biology, Institute of Research and Development, Duy Tan University, K7/25 Quang Trung, Da Nang City, Viet Nam.

\section{Acknowledgements}

We thank to Prof. Dr. Thomas Bock, Robert Koch Institute, Berlin, Germany for kindly providing pHDV3 plasmid.

\section{Competing interests}

The authors declare that they have no competing interests.

\section{References}

1. Hadziyannis SJ. Review: hepatitis delta. J Gastroenterol Hepatol. 1997:12:289-98.

2. Rizzetto M. Hepatitis D: thirty years after. J Hepatol. 2009;50:1043-50.

3. Abbas Z. Hepatitis D: scenario in the Asia-Pacific region. World J Gastroenterol. 2010;16:554

4. Wang KS, Choo QL, Weiner AJ, Ou JH, Najarian RC, et al. Structure, sequence and expression of the hepatitis delta (delta) viral genome. Nature. 1986;323:508-14.

5. Kuo MY, Sharmeen L, Dinter-Gottlieb G, Taylor J. Characterization of self-cleaving RNA sequences on the genome and antigenome of human hepatitis delta virus. JVirol. 1988;62:4439-44.

6. Smedile A, Asey JL, Cote P. Hepatitis D viremia following orthotopic liver transplantation involves a typical HDV virion with a hepatitis B surface antigen envelope. Hepatology. 1998;27:1723-9.

7. Abou-Jaoude G, Sureau C. Entry of hepatitis delta virus requires the conserved cysteine residues of the hepatitis B virus envelope protein antigenic loop and is blocked by inhibitors of thiol-disulfide exchange. J Virol. 2007:81:13057-66.

8. Dény P. Hepatitis delta virus genetic variability: from genotypes I, II, III to eight major clades? Curr Top Microbiol Immunol. 2006;307:151-71. 
9. Huang C-R, Lo SJ. Evolution and diversity of the human hepatitis D virus genome. Adv Bioinform. 2010;2010:1-9.

10. Dugo E, Paroli M, Palmieri G, Giuseppetti R, Argentini C, et al. Immunization of woodchucks with adjuvanted sHDAg (p24): immune response and outcome following challenge. Vaccine. 2004;22:457-66.

11. Shiau YT, Huang YH, Wu JC, Tao MH, Syu W, et al. Analysis of humoral immunity of hepatitis D virus DNA vaccine generated in mice by using different dosage, gene gun immunization, and in vivo electroporation. JCMA. 2006;69:7-13.

12. Chiang YW, Wu JC, Wang KC, Lai CW, Chung YC, et al. Efficient expression of histidine-tagged large hepatitis delta antigen in baculovirus-transduced baby hamster kidney cells. World J Gastroenterol. 2006;12:1551-7.

13. Calogero R, Barbieri U, Borla M, Osborne S, Poisson F, et al. Purification of recombinant hepatitis delta antigen expressed in E. coli cells. FEBS Lett. 1993;318:322-4

14. Gt Sheu, Mm Lai. Recombinant hepatitis delta antigen from E. coli promotes hepatitis delta virus RNA replication only from the genomic strand but not the antigenomic strand. Virology. 2000;278:578-86.
15. Hwang SB, Lee CZ, Lai MMC. Hepatitis delta antigen expressed by recombinant baculoviruses: comparison of biochemical properties and post-translational modifications between the large and small forms. Virology. 1992;190:413-22.

16. Li YJ, Macnaughton T, Gao L, Lai MMC. RNA-templated replication of hepatitis delta virus: genomic and antigenomic RNAs associate with different nuclear bodies. JVirol. 2006;80:6478-86.

17. Popper H, Thung SN, Gerber MA, Hadler SC, De Monzon M, et al. Histologic studies of severe delta agent infection in Venezuelan Indians. Hepatology. 1983;3:906-12.

18. Schwoebel ED, Moore MS. The control of gene expression by regulated nuclear transport. Essays Biochem. 2000;36:105-13.

19. Van Der Geer P. Phosphorylation of LRP1: regulation of transport and signal transduction. Trends Cardiovasc Med. 2002;12:160-5.

20. Hwang SB, Lai MM. Isoprenylation masks a conformational epitope and enhances trans-dominant inhibitory function of the large hepatitis delta antigen. J Virol. 1994;68:2958-64.

\section{Submit your next manuscript to BioMed Central and we will help you at every step:}

- We accept pre-submission inquiries

- Our selector tool helps you to find the most relevant journal

- We provide round the clock customer support

- Convenient online submission

- Thorough peer review

- Inclusion in PubMed and all major indexing services

- Maximum visibility for your research

Submit your manuscript at www.biomedcentral.com/submit 